\title{
Eudiaptomus gracilis in Italy: how, where and why
}

\author{
Nicoletta RICCARDI* and Giampaolo ROSSETTI ${ }^{1)}$ \\ CNR - Institute of Ecosystem Study, Largo Tonolli 50, 28922 Verbania Pallanza, Italy \\ ${ }^{1)}$ Department of Environmental Sciences, University of Parma, Viale G.P. Usberti 33A, 43100 Parma, Italy \\ *e-mail corresponding author: n.riccardi@ise.cnr.it
}

\begin{abstract}
Eudiaptomus gracilis, one the most widely distributed calanoid copepod species in Europe, was not reported in Italy prior to the late 1980s. Since then, E. gracilis has spread to an increasing number of Northern Italian water bodies where an indigenous calanoid copepod, E. padanus, was commonly present and abundant. In some instances, the former species has displaced the latter. Morphological and ecological similarities between the two species suggest that competitive exclusion may explain this substitution. The establishment of $\mathrm{E}$. gracilis seems to be limited to relatively small, eutrophic water bodies, which represent the majority of floodplain lakes in Northern Italy. The very recent colonization of oligo-mesotrophic Lake Maggiore - one of the largest Italian lakes - may allow for an examination both of the invasion process and its consequences for the abundant E. padanus population. Establishment of $\mathrm{E}$. gracilis in Lake Maggiore could accelerate the spread of the species to other lakes in the region. Indeed, due to its high connectivity, Lake Maggiore could become an invasion hub in a manner consistent with that reported for other invaders in lakes around the world.
\end{abstract}

Key words: freshwater calanoids, non-indigenous species, endemic species, species replacement, geographic distribution

\section{INTRODUCTION}

Until the last decades of the past century, the Alps and the Mediterranean Sea seemingly represented an efficient barrier against the entrance of non-indigenous species (NIS) species in Italian inland water bodies, thus enabling several endemic species to maintain themselves in their native environments. With the exponentially increasing rate of human-mediated introductions of NIS all over the world, natural barriers no longer provide effective protection (e.g., Rahel 2007), and any environment is potentially receptive to NIS invasions. An increasing number of non-indigenous zooplankton species have being reported in Italian freshwater bodies since the 1980's (e.g., Ferrari et al. 1992; Rossetti et al. 1996; Riccardi et al. 2004; Margaritora 2005; Stoch 2005). Some of these species were only occasionally found, such as the freshwater calanoid Boeckella triarticulata (Ferrari et al. 1992; Ferrari \& Rossetti 2006), others seemingly failed to establish successfully after a few years (e.g., Daphnia parvula; Riccardi et al. 2004; Riccardi, unpublished data), while others successfully established permanent populations and extend their distribution to more water bodies. The freshwater calanoid copepod Eudiaptomus gracilis is a member of the latter group (Rossetti et al. 1996; Riccardi \& Giussani 2007).

The differential success of invaders is not surprising since one of the main conclusions that has emerged from invasion studies is that the successful establishment of a NIS is an improbable event, and that many failed attempts occur for every successful one (William- son 1996). Indeed, once introduced into a new habitat, an invader has to pass through sequential "filters" in the invasion sequence (e.g., Williamson \& Fitter 1996; Muirhead \& MacIsaac 2005) before becoming successfully established. The second filter encompasses environmental tolerance to ambient physical and chemical conditions. Finally, the success of invasions depends strongly on community characteristics, including the diversity of the resident species pool (e.g., Case 1990; Tilman 1997; Levine 2000; Louette et al. 2006). This finding is consistent with the classical theory that linked environment stability to community diversity. It also represents successful integration of the NIS into the biological community of the novel habitat. Integration requires that the NIS sustain predation and competition with existing native species. Given the complexity of processes that underlie biological invasions, many hypothesis have been formulated, each of which has been shown to help explain some invasions (Alpert 2006). A central role is often recognized to species life history traits by the many ecological hypotheses based on niche trade-off models (e.g., Hutchinson 1951; Tilman 2004), while stochastic effects (i.e., propagule abundances and introduction pressure) are mostly invoked by neutral models (e.g., Hubbell 2001; Alonso et al. 2006) to predict invasion dynamics and species invasiveness. In particular, according to classical tradeoff based niche theories, the outcome of competition can produce niche partitioning, leading to coexistence of NIS and native species, or displacement of either the NIS or native species. In this view, Riccardi \& Giussani (2007) suggested that the freshwater copepod Eudiaptomus padanus, one of the most common calanoid spe- 
Tab. 1. The distribution of Eudiaptomus gracilis in Italian water bodies and the year of the first finding of this species.

\begin{tabular}{llll}
\hline Site & Type & Year & Reference \\
\hline 1 Lake Sirio & Small, meso-eutrophic & 1980 & de Bernardi et al. 1984 \\
2 Lake Lugano & Large, eutrophic & 1988 & Polli \& Simona 1992 \\
3 Lake Candia & Shallow, eutrophic & 1989 & Riccardi \& Giussani 2007 \\
4 Lanca del Rottone & Backwaters, Ticino River & 1990 & Cazzalini \& Sconfietti 1993 \\
5 Lanca del Topo & Backwaters, Ticino River & 1990 & Cazzalini \& Sconfietti 1993 \\
6 Lake Isola Giarola & Quarry lake, Po River & 1991 & Rossetti et al. 1996 \\
7 Lake Endine & Relatively large, eutrophic & 1994 & Verga 2003 \\
8 Cava Vecchia & Sand pit & 2000 & Rossetti et al. 2003b \\
9 Terzo Casone & Sand pit & 2001 & Rossetti et al. 2003a \\
10 Brusa Vecchia & Sand pit & 2001 & Rossetti et al. 2003a \\
11 Lake Pusiano & Relatively large, eutrophic & 2002 & Osservatorio dei laghi Lombardi 2005 \\
12 Po River & Potamal river segment & 2003 & Ferrari et al. 2006 \\
13 Cà Stanga & Sand Pit & 2004 & Tavernini \& Rossetti (unpublished) \\
14 Lake Maggiore & Large, oligo-mesotrophic & 2006 & Visconti et al. 2007 \\
\hline
\end{tabular}

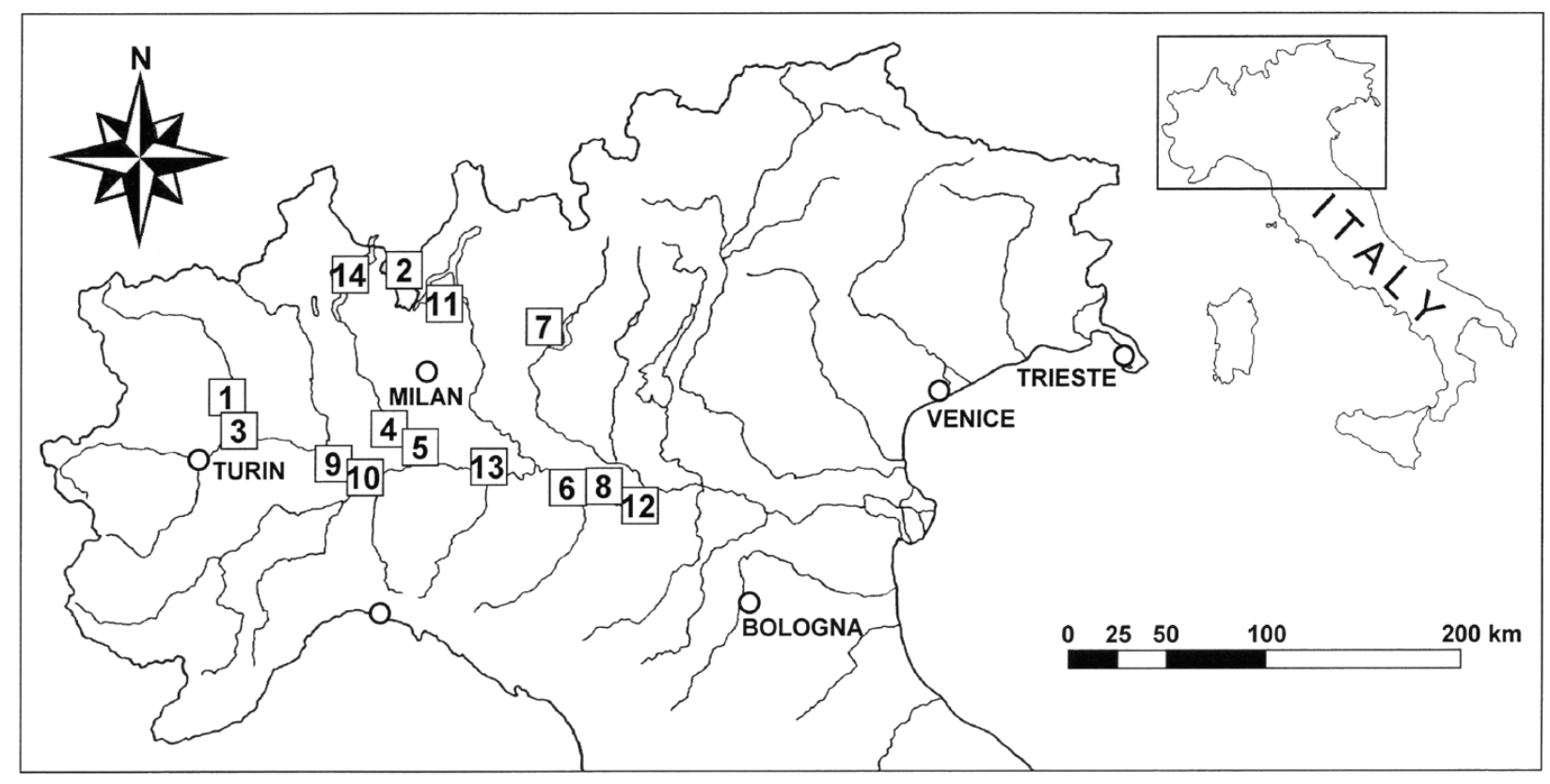

Fig. 1. Map showing the distribution of Eudiaptomus gracilis in Italy (updated from Stoch 2005). Sites numbered as in table 1.

cies both in the prealpine Italian regions (subspecies padanus padanus) and in the peninsular area (subspecies padanus etruscus and etruscosexsetosus) (Stella 1984; Dussart \& Defaye 2002), might have been competitively displaced by the closely related $E$. gracilis in an increasing number of environments in Northern Italy.

The present study aims to assess the available information on the ecology of both the native and invading copepod species, and on the actual distribution of E. gracilis in Italy in the attempt to evaluate the potential for future range expansion and its consequences for the endemic freshwater taxa.

\section{RESULTS AND DISCUSSION}

Current knowledge on the distribution of E. gracilis in Italy is summarized in table 1 and figure 1 . The first records date to 1980 , in which the species was described in the small $\left(0.3 \mathrm{~km}^{2}\right)$, meso-eutrophic (mean total phosphorus concentration $73 \mu \mathrm{g} \mathrm{L}^{-1}$; Regione Piemonte 2004) Lake Sirio. The most recent record of introduction is for 2006 with reference to the large $\left(212 \mathrm{~km}^{2}\right)$ oligo-mesotrophic (mean total phosphorus concentration 10-11 $\mathrm{g} \mathrm{L} \mathrm{L}^{-1}$; Regione Piemonte 2004) Lake Maggiore. During this time interval several other waterbodies have been successfully colonized, most of which are represented by gravel pits, river pools and backwaters or eutrophic lakes. Eudiaptomus padanus was previously present in four of these water bodies and it is still present in the most recently colonized Lake Maggiore.

Table 2 summarizes the main ecological characteristics of E. padanus and E. gracilis. The former has a very narrow geographic distribution, while the latter is broadly distributed throughout Europe and into North America, Siberia, China and Israel (Gaviria 1998; Dus- 
Tab. 2. Geographic distribution and ecological characteristics of Eudiaptomus padanus padanus and E. gracilis.

\begin{tabular}{|c|c|c|}
\hline & E. padanus padanus & E. gracilis \\
\hline Distribution & limited to Northern Italy & $\begin{array}{l}\text { broad geographic distribution: Europe, North } \\
\text { America, Asia }\end{array}$ \\
\hline \multicolumn{3}{|l|}{ Habitat characteristics: } \\
\hline Water body type & $\begin{array}{l}\text { Large and small floodplain water bodies (lakes, perifluvial } \\
\text { pools and backwaters) }\end{array}$ & $\begin{array}{l}\text { Large and small lowland and mountain water bodies } \\
\text { (lakes, rivers, perifluvial pools and backwaters) }\end{array}$ \\
\hline Trophic state & Oligo- to eutrophic & Oligo- to eutrophic \\
\hline Sensitivity to eutrophication & Reduction until elimination from highly eutrophic lakes & Highly tolerant \\
\hline Dietary items & unknown & Phytoplankton, bacteria, detritus \\
\hline Seasonal cycle & Eurythermic, perennial with continuous recruitment & Eurythermic, perennial with continuous recruitment \\
\hline
\end{tabular}

sart \& Defaye 2002). Both species inhabit a wide variety of habitat typologies, but only E. gracilis is found in slow-flowing rivers and in mountain lakes.

Both E. padanus and E. gracilis seem to be tolerant to a wide range of trophic conditions. However, $E$. padanus was reported to be eliminated from lakes undergoing severe eutrophication, including Lake Lugano, Italy (e.g., Ravera 1977). Conversely, E. gracilis seems tolerate highly eutrophic conditions, a characteristic which enabled this species to colonize Lake Lugano about forty years after E. padanus had been eliminated.

No information is available on the diet requirements of E. padanus, but like most calanoid copepods it has generally been considered as essentially herbivorous. Even though a similar herbivorous diet characterizes $E$. gracilis, the latter can survive for long periods of time feeding on bacteria and organic detritus (Nauwerk 1962). Both species are eurythermic and perennial with egg production throughout the year (e.g., Elster 1954; Ravera 1954, 1955; Hofmann 1979; Santer et al. 2000). In Lake Candia the two species displayed substantially similar seasonal patterns and reproductive cycles (Riccardi \& Giussani 2007). However, E. padanus has greater clutch size of smaller sized eggs relative to $E$. gracilis. Although total reproductive output (egg volume $\times$ clutch size) was higher in $E$. padanus than in E. gracilis, the ratio of clutch volume to female body volume is similar in the two species, indicating that energy investment in reproduction is the same on a weight-specific basis. Since the rate of clutch production might be expected to be similar, interspecific differences in developmental rates and/or juvenile mortality have been suggested as a reason for the observed species replacement (Riccardi \& Giussani 2007). The lower death rate and higher adult/egg ratio of E. gracilis observed in Lake Candia seems to support this hypothesis. Moreover, a comparison of temperature dependent development rates of $E$. padanus (Ravera, unpublished) with those of E. gracilis (Munro 1974) indicates that the latter species develops at twice the rate from egg to adult.
Invasion by $E$. gracilis is broadly consistent with expectations based on life-history. Among the traits that characterize a good invader, a high dispersal capacity and a type $r$ demographic strategy, along with the physiological capacity to tolerate and reproduce in a wide range of environmental conditions, are considered essential (e.g., Ehrlich 1986; McMahon 2002). Even though E. gracilis lacks diapausing eggs (e.g., Santer et al. 2000; Bohonak et al. 2006), which are known to enhance dispersal potential (e.g., Bilton et al. 2001; Panov et al. 2004), at least for short distances (Zeller et al. 2006), its wide distribution throughout different continents in water bodies of different typologies (Gaviria 1998; Dussart \& Defaye 2002) indicates a high dispersal ability as well as an ability to adapt to different local conditions. Data on the recent colonization of Northern Italian water bodies seem to provide further and strong evidence of its wide ecological tolerance. Indeed, it succeeded in establishing permanent populations in lakes and water bodies (e.g., lakes Lugano, Endine and Pusiano) in which trophic and/or physico-chemical conditions appeared to be unsuitable for calanoid copepod survival. While eutrophication was the most likely reason for the elimination of calanoid copepods (Eudiaptomus padanus and Mixodiaptomus laciniatus) from Lake Lugano (Ravera 1981), a high calcium concentration was hypothesized to be the reason for the lack of calanoid copepods in lakes Endine and Pusiano (e.g., Bonomi et al. 1967; Vighi 1977). E. gracilis establishment in marginal habitats, including river backwaters and slow-flowing river stretches, provides further support of its ability to tolerate even extremely harsh conditions. By contrast, the narrow distribution range of $E$. padanus suggests that it should have a very limited dispersal capacity (at least over long distances), while the comparatively limited set of environmental conditions which seem to enable E. padanus survival gives evidence of its narrower tolerance limits.

In at least three of the newly invaded sites (Lake Isola Giarola, Lake Brusa Vecchia and Lake Candia), $E$. gracilis establishment occurred concomitant with the 
reduction in abundance or elimination of the native species (Viaroli et al. 2002; Rossetti et al. 2003a; Riccardi \& Giussani 2007). It is possible that similar reductions in native copepods have occurred in other recently invaded but less closely monitored lakes. Indeed, in most of the water bodies where the presence $E$. gracilis was reported, little or no information on the pre-invasion zooplankton composition is available to make appropriate contrasts. The leading hypothesis for this species replacement in Lake Candia is that E. gracilis is a superior competitor over native E. padanus (Riccardi \& Giussani 2007), however other possibilities (e.g., apparent competition) cannot be dismissed. In addition, it is not clear whether environmental quality may influence the possible indirect interactions between $E$. gracilis and E. padanus. Laboratory investigations are necessary to confirm the possible role of competition in this species replacement, though additional data from other systems may also provide insight into interspecific competition. Studies are in progress on Lake Maggiore to confirm invader colonization throughout this large lake and to evaluate its effects on the resident species. Indeed, the probability of a coexistence through niche partitioning is likely to be higher in a large and deep lake, such as Lake Maggiore, than in small and relatively shallow water bodies as those where species replacement occurred.

A survey of the lakes laying in the Lake Maggiore watershed revealed that E. padanus is still present as the unique calanoid copepod (Riccardi, unpublished data), except in Lake Lugano, which drains into Lake Maggiore through the River Tresa. It is therefore very likely that the source of Lake Maggiore propagules is the population in Lake Lugano, which established in 1988. The 20 year interval that elapsed between when the species was detected in these two lakes indicates that a significant lag period may be required before $E$. gracilis is sufficiently dense as to be detected. The relatively long time taken for E. gracilis effective transfer to Lake Maggiore via direct river connection (about 21 $\mathrm{km}$ ) seems to be in agreement with the lack of easily transportable diapausing eggs. Indeed, the transport of the active population component by water currents can be expected to be less effective than that of resting eggs because of the loss by mortality induced by the physical properties of the connecting elements. Since the Tresa is a torrent-like river, a substantial reduction of the flow of live individuals during the transport from Lake Lugano to Lake Maggiore can be reasonably predicted. The contrasting effects of changed environmental conditions and biotic resistance may have contributed to the time needed for successful establishment. Accordingly, Michels et al. (2001) measured a very low relative contribution of dispersing individuals to the total population size in target populations in a system of interconnected ponds, even though large numbers of individuals were transported from source populations.
Lake Maggiore has been studied for a number of years to assess whether E. gracilis was not present (e.g., Manca et al. 2006; Visconti et al. 2007). Analyses indicated that the species was not present despite high propagule pressure. Thus initial reports were consistent with the view that physical/chemical or biological interactions were preventing invasion in spite of high introduction effort. However, the recent observation of $E$. gracilis in the lake now provides support to propagule pressure theory (e.g., Williamson 1996; Lonsdale 1999; Kolar \& Lodge 2001). Provided that E. gracilis will become permanently established in Lake Maggiore, this is likely to become an invasion hub facilitating further invasions owing both to natural and human-mediated connections to other water bodies in the region (e.g., Muirhead \& MacIsaac 2005). Indeed, while most of the previously invaded sites are relatively unimportant sources (i.e., have few natural and human mediated connections), Lake Maggiore is one of the largest Italian lakes with a high recreational value and a high connectivity via its effluent (Ticino River) and departing boaters and anglers. Therefore, an increasing speed of E. gracilis diffusion could be tentatively predicted. In addition, the Lake Maggiore example also assumes a relevant predictive importance in relation to the fate of E. padanus. In fact, if even in this case a species replacement will occur, E. padanus should be considered a "fugitive species", sensu Elton and Hutchinson, whose distribution range is likely to become progressively restricted following the wave of E. gracilis expansion.

\section{ACKNOWLEDGEMENTS}

We are grateful to Oscar Ravera, Hugh MacIsaac and Marina Manca for their valuable comments on an earlier draft of the manuscript and to Sandra Spence for the English revision.

\section{REFERENCES}

Alonso, D., R.S. Etienne \& A.J. McKane. 2006. The merits of neutral theory. Trends Ecol. Evol., 21: 451-457.

Alpert, P. 2006. The advantage and the disavantages of being introduced. Biological Invasions, 8: 1523-1534.

Bilton, D.T., J. Freeland, \& B. Okamura. 2001. Dispersal in freshwater invertebrates. Ann. Rev. Ecol. Syst., 32: 159181.

Bohonak, A.J., M.D. Holland, B. Santer, M. Zeller, C.M. Kearns \& N.G. Hairston Jr. 2006. The population genetic consequences of diapause in Eudiaptomus copepods. Arch. Hydrobiol., 167:183-202.

Bonomi, G., C. Bonacina \& I. Ferrari. 1967. Caratteristiche chimiche, plancton e benton nel quadro evolutivo recente dei laghi briantei. Mem. Ist. ital. Idrobiol., 21: 241-287.

Case, T.J. 1990. Invasion resistance arises in strongly interacting species-rich model competition communities. Proc. Nat. Acad. Sci., 87: 9610-9614.

Cazzalini, O. \& R. Sconfietti. 1993. Lanche del basso corso del Ticino a confronto. II. Ecologia e dinamica dei popolamenti zooplanctonici. Mem. Soc. Tic. Sci. Nat., 4: 175-184. 
de Bernardi, R., G. Giussani, R. Mosello \& I. Origgi. 1984. Quadro limnologico di cinque piccoli laghi piemontesi (Avigliana, Trana, Candia, Viverone e Sirio). Documenta Ist. ital. Idrobiol., 5:1-97.

Dussart, B. \& D. Defaye, 2002. World directory of Crustacea Copepoda of inland waters. I - Calaniformes. Backuhys Publishers, Leiden: $276 \mathrm{pp}$.

Ehrlich, P.R. 1986. Which animal will invade. In: Mooney, H.A. \& Drake J.A. (Eds), Ecology of Biological Invasions of North America and Hawaii. Springer-Verlag, New York, :79-95.

Elster, H.J. 1954. Über die Populationsdynamik von Eudiaptomus gracilis und Heterocope borealis Fisher im Bodensee-Obersee. Arch. Hydrobiol. Suppl., 20: 546-614.

Ferrari, I., A. Farabegoli, A. Pugnetti, \& E. Stella. 1992. The occurrence of a calanoid Australasian species, Boeckella triarticulata (Thompson), in fish ponds of Northern Italy. Verh. Internat. Verein. Limnol., 24: 2822-2827

Ferrari I. \& G. Rossetti. 2006. New records of the centropagid Boeckella triarticulata (Copepoda: Calanoida) in Northern Italy: evidence of a successful invasion? Aquatic Invasions, 1: 219-222.

Ferrari, I., S. Viglioli, P. Viaroli \& G. Rossetti. 2006. The impact of the drought event of summer 2003 on the zooplankton of the Po River (Italy). Verh. Internat. Verein. Limnol., 29: 2143-2149.

Gaviria, S. 1998. Checklist and distribution of the free-living copepods (Arthropoda: Crustacea) from Austria. Ann. Naturhist. Mus. Wien, 100 B: 539-594.

Hofmann, W. 1979. Characteristics of syntopic populations of Eudiaptomus gracilis (Sars) and E. graciloides (Lilljeborg) in three lakes of different trophic levels. Arch. Hydrobiol., 86: 1-12.

Hubbell, S.P. 2001. The Unified Neutral Theory of Biodiversity and Biogeography. Monographs in Population Biology, Princeton Univ. Press, Princeton: 448 pp.

Hutchinson, G.E. 1951. Copepodology for the ornithologist. Ecology, 32: 571-577.

Kolar, C.S. \& D.M. Lodge. 2001. Progress in invasion biology: predicting invaders. Trends Ecol. Evol., 16: 199-204.

Levine, J.M. 2000. Species diversity and biological invasions: relating local process to community patterns. Science, 288 : 852-854.

Lonsdale W.M. 1999. Global patterns of plant invasions and the concept of invisibility. Ecology, 80: 1522-1536.

Louette, G., M. Vander Elst \& L. De Meester. 2006. Establishment success in young cladoceran communities: an experimental test. Limnol. Oceanogr., 51: 1021-1030.

Manca, M., A. Visconti, R. Piscia \& R. de Bernardi. 2006. Popolamenti planctonici. Dinamica stagionale del popolamento zooplanctonico. In: R. Bertoni (Ed.). Ricerche sull'evoluzione del Lago Maggiore. Aspetti limnologici. Programma quinquennale 2003-2007. Campagna 2005. Commissione per la Protezione delle Acque Italo-Svizzere (Ed.): 60-63.

Margaritora F.G. 2005. Crustacea Branchiopoda Cladocera. In: Ruffo S., Stoch F. (Eds), Checklist e distribuzione della fauna italiana. Memorie del Museo Civico di Storia Naturale di Verona, 2. serie, Sezione Scienze della Vita, 16: 87-89.

McMahon, R.F. 2002. Evolutionary and physiological adaptations of aquatic invasive animals: $r$ selection versus resistance. Can. J. Fish. Aquat. Sci., 59: 1235-1244.

Michels, E., K. Cottenie, L. Neys \& L. De Meester. 2001. Zooplankton on the move: first results on the quantification of dispersal of zooplankton in a set of interconnected ponds. Hydrobiologia, 442: 117-126.

Muirhead, J.R. \& H.J. MacIsaac. 2005. Development of inland lakes as hubs in an invasion network. J. Appl. Ecol., 42: $80-90$.
Munro, I.G. 1974. The effect of temperature on the development of egg, naupliar and copepodite stages of two species of copepods, Cyclops vicinus Uljianin and Eudiaptomus gracilis Sars. Oecologia, 16: 335-367.

Nauwerk, A. 1962. Nicht-algishe ernahrung bei Eudiaptomus gracilis (Sars). Arch. Hydrobiol., 25: 393-400.

Osservatorio dei Laghi Lombardi. 2005. Qualità delle acque lacustri in Lombardia. $1^{\circ}$ Rapporto OLL 2004, Regione Lombardia, ARPA Lombardia, Fondazione Lombardia per l'Ambiente e IRSA/CNR: $351 \mathrm{pp}$.

Panov, V.E., P.I. Krylov \& N. Riccardi. 2004. Role of diapause in dispersal and invasion success by aquatic invertebrates. J. Limnol., 63 (Suppl. 1): 56-69.

Polli, B. \& M. Simona. 1992. Qualitative and quantitative aspects of the evolution of the planktonic populations in Lake Lugano. Aquat. Sci., 54: 303-320.

Rahel, F.J. 2007. Biogeographic barriers, connectivity and homogeneization of freshwater faunas. Freshwat. Biol., 52: 696-710.

Ravera, O. 1954. La struttura demografica dei Copepodi del Lago Maggiore. Mem. Ist. ital. Idrobiol., 8: 109-150.

Ravera, O. 1955. Seasonal variations of the reproduction rate in pelagic copepods of Lake Maggiore. Verh. int. Verein Limnol., 12: 436-446.

Ravera, O. 1977. Effects of eutrophication on the zooplankton of a subalpine lake: Lake Lugano. in: Downey, W.K. \& G. $\mathrm{Ni}$ Uid (Eds), Lake pollution eutrophication control. Proc. Seminar Killarney, Ireland, May 1977, Ntl. Sc. Council, Dublin: 97-104.

Ravera, O. 1981. The influence of nutrient enrichment on freshwater zooplankton. In: Restoration of lakes and inland waters. Int. Symp. Inland Waters and lake restoration. Portland. Sept 8-12/80. EPA 440/5-81-010: 210-217.

Regione Piemonte. 2004. Indagini e studi finalizzati alla predisposizione del Piano di tutela delle Acque (D. Lgs. 152/99). Allegato tecnico: $184 \mathrm{pp}$.

Riccardi, N. \& G. Giussani. (2007). The relevance of life history traits in the establishment of the invader Eudiaptomus gracilis and the extinction of Eudiaptomus padanus in Lake Candia (Northern Italy): evidence for competitive exclusion? Aquatic Ecology (in press, DOI 10.1007/s10452-006-9061-3).

Riccardi, N., G. Giussani, F. Margaritora \& B. Couchaud. 2004. Population dynamics of the pioneer population of Daphnia parvula Fordyce during the invasion of Lake Candia (Northern Italy). J. Limnol., 63: 44-52.

Rossetti, G., B. Dussart \& P. Viaroli. 1996. Finding of the calanoid Eudiaptomus gracilis (Sars) in perifluvial environments of the Po River. Mem. Ist. ital. Idrobiol., 54: 51-59.

Rossetti, G., M. Bartoli, L. Ariotti, \& P. Viaroli. 2003a. Studio idrobiologico di ambienti acquatici golenali del Parco Fluviale del Po e dell'Orba (Alessandria). Biol. Amb. 17: 53-64.

Rossetti, G., F. Tireni, S. Viglioli \& I. Ferrari. 2003b. Ricerche ecologiche in un ambiente acquatico della golena del Po nei pressi di Casalmaggiore. St. Trent. Sc. Nat. - Acta Biol., 80: 193-200.

Santer, B., E. Blohm-Sievers, C.E. Cáceres \& N.G. Hairston Jr. 2000. Life-history variation in the coexisting freshwater copepods Eudiaptomus gracilis and Eudiaptomus graciloides. Arch. Hydrobiol., 149: 441-458.

Stella, E. 1984. Crustacea - Copepoda: Calanoida d'acqua dolce. Calderini, Bologna: $101 \mathrm{pp}$.

Stoch, F. 2005. Crustacea Copepoda Calanoida. In: Ruffo, S. \& F. Stoch (Eds), Checklist e distribuzione della fauna italiana. Memorie del Museo Civico di Storia Naturale di Verona, 2. serie, Sezione Scienze della Vita, 16: 91-92.

Tilman, D. 1997. Community invasibility, recruitment limitation, and grassland biodiversity. Ecology, 78: 81-92.

Tilman, D. 2004. Niche tradeoffs, neutrality, and community structure: a stochastic theory of resource competition, 
invasion, and community assembly. Proc. Nat. Acad. Sci., 101: 10854-10861.

Verga, E.C. 2003. Evoluzione pluriennale della comunità zooplanctonica del Lago di Endine. Graduation thesis, University of Milan.

Viaroli, P., I. Ferrari \& G. Rossetti. 2002. Long-term limnological research in a quarry lake of the Po River, Italy. Verh. Internat. Verein. Limnol., 28: 576-581.

Vighi, M. 1977. Popolamenti zooplanctonici. In: Gerletti, M. \& R. Marchetti (Eds), Indagini sui laghi della Brianza, Quaderni Ist. Ric. Acque, 19: 185-195.

Visconti, A., M. Manca \& R. de Bernardi. (2007). Sulla comparsa di Eudiaptomus gracilis, specie alloctona, nel Lago Maggiore. In. . In: R. Bertoni (Ed.). Ricerche sull'evolu- zione del Lago Maggiore. Aspetti limnologici. Programma quinquennale 2003-2007. Campagna 2006. Commissione per la Protezione delle Acque Italo-Svizzere (Ed.): (in press).

Williamson M. 1996. Biological Invasions. Chapman and Hall, London: 244 pp.

Williamson, M. \& A. Fitter. 1996. The varying success of invaders. Ecology, 77: 1661-1666.

Zeller, M., T.B.H. Reusch \& W. Lampert. 2006. A comparative population genetic study on calanoid freshwater copepods: investigation of isolation-by-distance in two Eudiaptomus species with a different potential for dispersal. Limnol. Oceanogr., 51: 117-124.

Received: March 2007

Accepted: May 2007 